\title{
The Influence of Students Information Literacy Competency on Creativity under the Regulation of Classroom Climate
}

\author{
Cheng-Ping Chang1, Yu-Han Lian1, Dan-Dan Zhang2, Si-Chen Wang2,3* \\ ${ }^{1}$ Department of Education, National University of Tainan, Taiwan \\ ${ }^{2}$ School of Business, Macau University of Science and Technology, Macau, China \\ ${ }^{3}$ Kiang Wu Nursing College of Macau, Macau, China \\ Email: ${ }^{*}$ sichen@kwnc.edu.mo
}

Received 2 June 2016; accepted 17 July 2016; published 21 July 2016

Copyright (C) 2016 by authors and Scientific Research Publishing Inc.

This work is licensed under the Creative Commons Attribution International License (CC BY).

http://creativecommons.org/licenses/by/4.0/

(c) () Open Access

\begin{abstract}
This study mainly explores the impact of student's information literacy on student's creativity, the impact of classroom climate on student's creativity, and the moderatoring effects of classroom climate between the impact of student's information literacy on student's creativity. This study used the questionnaire surveys for data collection of senior grade elementary school students from Tainan. Survey participants consist of 349 students from 10 elementary schools. This research used SPSS20.0 to apply descriptive statistics, pears on correlation analysis, multiple regression analysis, and hierarchical linear modeling. Main findings of this study included the following. It is a positive impact of student's information literacy on student's creativity. It is a positive impact of classroom climate on student's creativity. And it is no moderatoring effects of classroom climate between the impact of student's information literacy on student's creativity. Finally, based on the results and analysis of this study, we make recommendations to school administrant, teachers and the future researchers.
\end{abstract}

\section{Keywords}

Student's Information Literacy, Student's Creativity, Classroom Climate

\section{Introduction}

With the rise of era of knowledge economy, various countries around the world have been fully aware that the

Corresponding author.

How to cite this paper: Chang, C.-P., Lian, Y.-H., Zhang, D.-D., \& Wang, S.-C. (2016). The Influence of Students Information Literacy Competency on Creativity under the Regulation of Classroom Climate. Creative Education, 7, 1551-1560.

http://dx.doi.org/10.4236/ce.2016.711160 
critical factor affecting competitive advantages in this fiercely competitive century is creativity. Countries, such as the US, Singapore, Japan, Australia, and Korea, all have aggressively developed educational policies for cultivating and improving creativity. The $21^{\text {st }}$ century can truly become “era of creativity” (Cheng, 2013; Florida, 2004). Creativity has become a critical factor to which Taiwan has to attach importance. Therefore, the government has proposed many relevant programs. It seems that "creativity” has become the beginning of a national movement (Cheng, 2013). In order to cultivate talents with creativity and create the kingdom of creativity, Ministry of Education has spread the educational seed of creativity to from colleges to elementary schools and junior high schools. Moreover, Ministry of Education firstly announced "White Paper on Creativity Educational Policies”, in order to achieve the goal of "Republic of Creativity (ROC)”. Based on the above, this study mainly intends to investigate the good approaches for improving creativity of higher grade elementary school students, which is research motivation 1 of this study.

On the other hand, the impact of information technologies on education is inevitable. Therefore, how do students respond to the impact of information technologies to further engage in effective learning has become an important issue to be discussed. Abundant information has been passed down rapidly to provide more convenient information retrieval channels, which changes the way how information is presented and transferred. How to obtain accurate and effective information is an issue to which people in the era of information explosion should pay attention. "Information literacy competency" has become the basic ability to be required by modern people. Relevant studies investigating creativity found that, personal traits, motivations, attitude, abilities, and interaction between individuals and environment all are the factors affecting creativity (Hunter, Bedell, \& Mumford, 2007; Simonton, 2009; Runco, 2007). Information literacy emphasizes that information literacy competency is a problem-solving process. In addition, creativity is also perceived as a cognitive thinking process, as well as problem-solving ability (Hennessey, 2003; Mayesky, 2005; Shalley, Zhou, \& Oldham, 2004). However, there are only a few studies investigating the influence of information literacy on creativity, which is research motivation 2 of this study.

"The faster the exchange is, the faster the innovation is". The best learning model of creativity is cluster-based learning model. When an individual is lone and alienated, it is impossible for him/her to display creativity (Amabile, 2001). The theory of 4Ps of creativity also verified that, development of creativity is the product of interactions between individuals and environment (Liang \& Wei, 2013). As a result, in a classroom, teacher and classmates play very important roles and can shape different classroom climate. However, there is a lack of studies investigating whether classroom climate can affect children's creativity, which is the research motivation 3 of this study.

The study by Hunter, Bedell and Mumford (2007) mentioned that, perceived climate in either individualbased level or group-based level can effectively predict the behaviors of creativity and innovation. From the perspective of interaction theory, a context has a direct influence of individual behaviors, and a context may even strengthen or weaken individual behaviors and states, as well as affect the directions and strengths of individual independent variables on individual dependent variables (Hsiao, 2011). Therefore, the context and atmosphere of classroom climate seems to have a moderating effect on students' information literacy competency and their creativity. However, both the foreign and domestic studies found that, there are only a very few studies investigating the influence of these three variables, and there are also limited studies investigating classroom climate as a moderator. Based on the above, this study intends to verify the moderator (classroom climate) for students' information literacy competency to affect their creativity, in order to clarify the influence of higher grade students' information literacy competency on their creativity, which is research motivation 4 of this study.

\section{Research Purposes}

Based on the above, this study used students' creativity as the dependent variable of this study, used students' information literacy competency as the independent variable of this study, and used classroom climate as the moderator. Therefore, the research purposes are as follows:

1) To understand the current status of students' information literacy competency, students' creativity, and classroom climate.

2) To investigate the influence of students' information literacy competency and classroom climate on their creativity.

3) To investigate the moderating effect of classroom climate in the influence of students' information literacy 
competency on their creativity.

\section{Literature Review}

Students' information literacy competency is defined as individuals’ full understanding of the processes, such as search, attainment, organizing, assessment, and utilization of the information they need, possession of basic ability to actually operate tools within information range, attention to information ethics, and maintenance of a positive and aggressive attitude towards information. Big6 model applies to students of all ages, and focuses on the process of development of problem-solving ability. The model of Seven Pillars of Information Literacy focuses on the process of development of information literacy, as well as the learning of skills and attitudes. Therefore, this study used these two models as the main theoretical foundation of this study. Students' creativity is defined as the development of traits and abilities of innovative concepts during the learning process of cognitive thinking and interactions with environment, as well as the generation of outcomes with originality and usefulness. The systematic perspective of Csikszentmihalyi’s (1996) creativity uses original and valuable thinking or products to determine creativity, suggests that the knowledge owned and experienced by individuals is the foundation of innovation, focuses on how individuals persuade others into accepting innovative ideas or products, and proposes the importance of gatekeepers during the development of creativity. Classroom climate is defined as personality traits of teachers and students in a class, teachers' teaching methods and students' interactions, students' exchanges, development of unique lasting atmosphere and culture under the influence of environment, and change in characteristics of everyone in a class. Field theory focuses on the dynamic mutual influences among individuals, environment, and group members, and attaches importance to interactive relationship among members. Need-press theory suggests that individuals will determine their behaviors according to internal personal needs and the feeling of external environmental pressure. Classroom as A Social System theory suggests that individual behaviors in a group are the outcome of interaction between system and personal factors.

Information literacy is critical thinking, problem solving, lifelong learning, independent thinking, learning of how to learn, and decision-making ability. From the process of creativity, creativity is also a problem-solving ability (Bröckling, 2006; Davis, 2009). The cultivation of information literacy can train students' problemsolving and critical thinking abilities. Moreover, information literacy has a positive predictive power for creativity. Therefore, information literacy has an influence on creativity. Making the best use of information ability can increase subject knowledge and problem-solving ability (AASL, 2009; Andretta, 2005; Bruce, 2008; Eisenberg, Lowe, \& Spitzer, 2004). Problem-solving and problem-discovering-based individual tasks can also stimulate students' creativity. Based on the said arguments and research findings, according to the influence of information literacy on creativity as discovered in the said studies, this study proposed $\mathrm{H} 1$ :

H1: Students' information literacy competency has a positive influence on their creativity.

“Environmental opportunities” in teachers' teaching indicates that teachers can use teacher-student interactions or classroom management to increase students' motivation to engage in creation. Students' intrinsic motivation can support and provide individuals or groups with the resources and opportunities to exert creativity, as well as immediately improve students’ creativity performance (Hsiao, 2011). In recent years, creativity-related studies have verified that, creativity tends to be affected by organizational environment and thus changed (Huang et al., 2011). Creativity education is mainly schools' operation of innovative learning environment and vivid teaching atmosphere. Creativity is developed through the interactions between individuals and environments (Simonton, 2009). Teachers can use teacher-student interactions or classroom management to enhance students' motivation to engage in creation. Students' creativity performance can be displayed and improved through interactions with environments and vivid classroom learning atmosphere. Therefore, environment is one of the important factors affecting cultivation of students' creativity. The development of creative behaviors is the mutual influence among individual traits, motivation, and external environment, as well as the diversified interactive process between individuals in social context and other individuals (Liang \& Wei, 2013). Therefore, classroom context is also the factor affecting students' learning motivation, while intrinsic work motivation and social environment context are the main factors affecting creativity (Lin and Nie, 2011). Moreover, the perspective of social interactions suggests that the classroom climate jointly created by teachers and students will affect students' development of creative thinking. Huang (2003) indicated that perceived classroom climate is signifi- 
cantly positively correlated with creativity tendency. Based on relevant arguments mentioned above and the research results, as well as the influence of classroom climate on creativity as mentioned in the aforementioned studies, this study proposed $\mathrm{H} 2$ :

H2: Classroom climate has a significantly positive influence on students' creativity.

It seems that teaching context arranged by teachers, interactions between teachers and peers, and social culture will affect students' information literacy competency and their creativity. Therefore, in the influence of information literacy on creativity, some factors also will interfere with the strength of such influence. Relevant studies found that, positive emotion is beneficial to divergent thinking, while negative emotion is beneficial to problem-solving ability. Both positive emotion and negative emotion can affect creativity (Gnezda, 2011). The study by Hunter, Bedell and Mumford (2007) mentioned that, it has been found that perceived climate in either individual-based level or group-based level can effectively predict the behaviors of creativity and innovation. Such climate factors play a role to strengthen or weaken the relationship between individual attitude and behaviors (Hsu et al., 2011). Moreover, in addition to directly affecting individual behaviors, group-based factors can also strengthen or weaken the strength or direction of relationship between independent variables of individual-based level and dependent variables of individual-based level (Hsiao, 2011). The study by Lin (2010) also found that, classroom management style has a significant moderating effect on students' creativity tendency. As a result, there may be relationships of various directions and strengths in students' creativity due to the level of classroom climate. The said arguments showed that, it seems that classroom climate can explain that students' information literacy competency is the moderator for their creativity. Based on the said relevant arguments and research results, this study proposed $\mathrm{H} 3$ :

H3: Classroom climate has a significant moderating effect on the influence of students' information literacy competency on their creativity.

\section{Research Design and Method}

\subsection{Research Structure}

The main purpose of this study is to investigate the influence of students' information literacy competency on their creativity, that of classroom climate on students' creativity and the moderating effect of classroom climate on the influence of students' information literacy competency on their creativity. In order to have an overall understanding on the investigations in this study, this study used research framework to explain the relationship between research variables in this study and various variables, as shown in Figure 1.

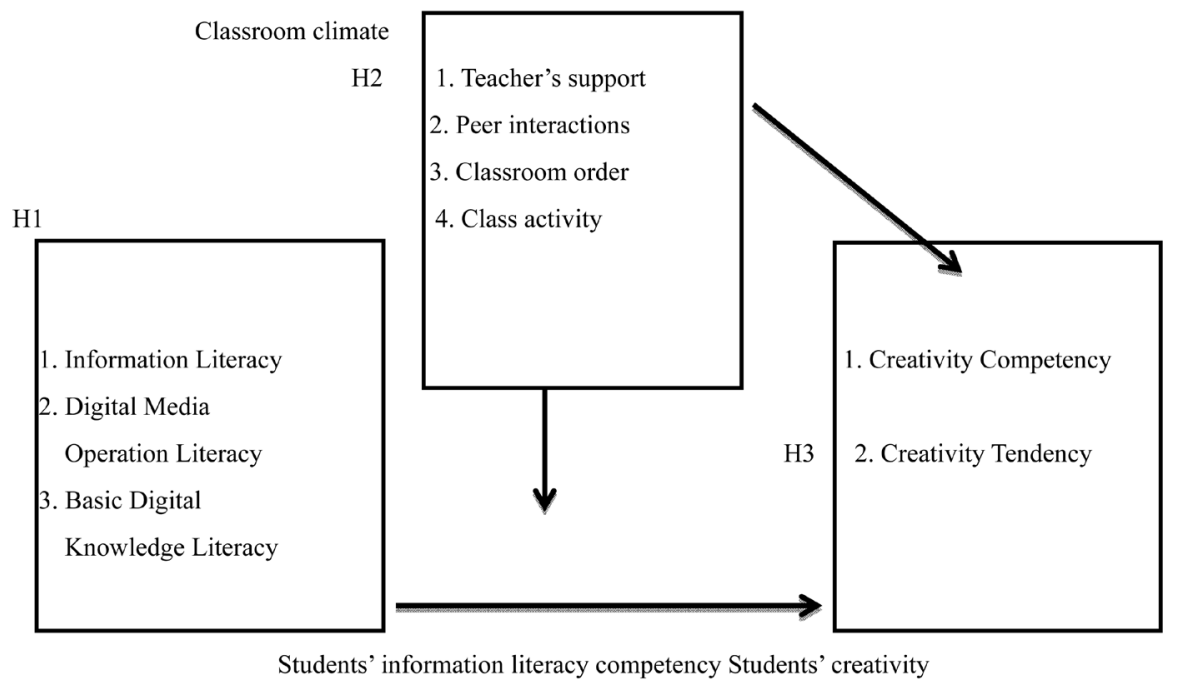

Figure 1. Research framework of this study. H1: Students’ information literacy competency has a significantly positive influence on their creativity. H2: Classroom climate has a significantly positive influence on students' creativity. H3: Classroom climate has a significant moderating effect on the influence of students' information literacy competency on their creativity. 


\subsection{Research Subjects and Sampling}

This study used stratified random cluster sampling to effectively enroll higher grade students in both private and public elementary schools in Tainan City as the research subjects. Stratified sampling can be used to test the difference in various subgroups in research population. In cluster sampling, group can be used as sampling unit. According to the school scale, this study used "stratification" to divide total number of classes into three zones to select various schools. In addition, this study used "random cluster" according to the proportion of various zones. In terms of the determination of sample size, 400 formal questionnaires were expected to be returned. Elementary schools were divided into three categories according to their scale: large schools have at least 25 classes, middle ones have 13 - 24 classes, and small ones have less than 12 classes. One grade-5 class and one grade-6 class were selected from each school, respectively, and this study intended to select classes from 10 public and private elementary schools in Tainan City. This study selected 5 schools where there were less than 12 classes (56.4\%), 2 schools where there were 13 - 24 classes (18\%), and 3 schools were there were at least 25 classes (25.6\%). In terms of the return of questionnaires, a total of 370 questionnaires were returned. After 21 invalid questionnaires were excluded, there were 349 valid questionnaires, with a valid return rate of $87.3 \%$.

\subsection{Research Tools}

This questionnaire includes the respondents' basic information. The basic information investigated in this study includes 5 factors: gender of student, gender of mentor, grade of student, administrative post of mentor, and scale of school class. These factors were used to understand respondents' attributes to facilitate further analysis. The detailed explanations are given as follows:

Gender of student: Male and female.

Grade of student: Grade 5 and grade 6.

Gender of mentor: Male and female.

Administrative post of mentor: Yes and no.

Scale of school class: Less than 12 classes, 13 - 24 classes, and at least 25 classes.

The name of scales are “The scale on students' information literacy competency, the scale on students' creativity and the scale on classroom climate". The "scale on students' information literacy competency" in this study used 5-point Likert scale for scoring. The average scores of various dimensions in the scale were used to determine students' perception. The higher the scale score was, the higher the students' self-perceived information literacy was. The lower the scale score was, the lower the students' self-perceived information literacy was. The "scale on students' creativity" used 5-point Likert scale for scoring. The average scores of various dimensions in the scale were used to determine students' perception. The higher the scale score was, the higher the students' self-perceived creativity was. The lower the scale score was, the lower the students' self-perceived creativity was. The "scale on classroom climate" used 5-point Likert scale for scoring. The average scores of various dimensions in the scale were used to determine students' perception. The higher the scale score was, the higher the students' self-perceived classroom climate was. The lower the scale score was, the lower the students' self-perceived classroom climate was.

\subsection{Validity and Reliability of Research Tools}

\section{Factor Analysis and Reliability Analysis}

The KMO value of the scale on students' information literacy competency was .893 ( $p<.001)$, so it applies to factor analysis. Approximate chi-square value of Bartlett spherical test was 1302.37, which reached significance. Therefore, there were common factors. The factor loading of various items in the scale was .476 - .851, and the variance explained by 3 factors was 28.926, 44.362, and 58.325, respectively. Based on the above, this study summarized 3 factors as follows: factor 1 "information literacy,” factor 2 "digital media operation literacy," and factor 3 "basic digital knowledge literacy." The results of reliability analysis on the scale showed that, $\alpha$ value of factor 1 information literacy was .911, that of factor 2 digital media operation literacy was .826, and that of factor 3 basic digital knowledge literacy was .736 . The total $\alpha$ value was .9 , suggesting that the reliability of the scale was good. The KMO value of the scale on students' creativity was .943 $(p<.001)$, so it applies to factor analysis. Approximate chi-square value of Bartlett spherical test was 1583.258, which reached significance. Therefore, there were common factors. The factor loading of various items in the scale was .395 - .81, and the 
variance explained by 2 factors was 37.112 and 61.489, respectively. Based on the above, this study summarized 2 factors as follows: factor 1 “creativity competency” and factor 2 "creativity tendency”. The results of the reliability analysis on the scale showed that, $\alpha$ value of factor 1 creativity competency was .94, and that of factor 2 creativity tendency was .855 . The total $\alpha$ value was .946 , suggesting that the reliability of the scale was good. The KMO value of the scale on classroom climate was .93 $(p<.001)$, so it applies to factor analysis. Approximate chi-square value of Bartlett spherical test was 2799.509, which reached significance. Therefore, there were common factors. The factor loading of various items in the scale was .518 - .799, and the variance explained by 4 factors was21.49, 41.264, 55.673, and 66.464, respectively. Based on the above, this study summarized 4 factors as follows: factor 1“teacher's support”, factor 2 "peer interactions”, factor 3 “classroom order”, and factor 4 "class activity."The results of the reliability analysis on the scale showed that, $\alpha$ value of factor 1 teacher's support was .923, that of factor 2 peer interactions was .921, that of factor 3 classroom order was .911, and factor 4 class activity was .685 . The total $\alpha$ value was .954 , suggesting that the reliability was good.

\section{Results and Discussion}

\subsection{Analysis on the Current Status of Students' Information Literacy, Students' Creativity and Classroom Climate}

The mean of overall students' information literacy was 3.90 (above average), suggesting that their information literacy performance in class in schools was above average. In terms of the mean score, the score of "digital media operation literacy" was the highest, while that of "information processing literacy" was the lowest. Therefore, the students were familiar with operation of computer and relevant peripheral products, and could use computer as media to communicate and exchange with other people. However, students' performance of understanding own problems, actively collecting data, finding out the focuses of data, reaching conclusions, and sharing with others was poorer. The mean of overall students' creativity was 3.83 (above average), suggesting that their creativity performance of above average. Therefore, students' creativity competency was good. In terms of the mean score, the score of "creativity competency" was the highest, while that of "creativity tendency" was the lowest. Therefore, the students were familiar with the use of many methods to express their own ideas, as well as the use of a proactive attitude to solve problems. However, the students' performance of being brave to contact unknown environment and positively facing failure and criticism was poorer. The mean of overall classroom climate was 3.90 (above average), suggesting that the perceived classroom climate of students in class in schools was above average. Therefore, the students' perceived classroom climate was good. In terms of the mean score, the score of "class activity" was the highest, while that of "classroom order" was the lowest. Therefore, students could significantly perceive the rules in classroom environment set up by mentor in class and use technology aids to receive teaching. However, the performance of class order and that of order control during mentor's absence were poorer.

\subsection{Multiple, Simultaneous Regression Analysis}

As shown in Table 1 , the $\mathrm{F}$ test value was $146.327(p<.001)$, reaching the significance. $\mathrm{R}^{2}$ was .557, suggesting that the students' sub-dimensions of information literacy could explain $55.7 \%$ of variance of their creativity. The regression analysis is summarized in Table 1 . The analysis found that, the VIF value of sub-dimensions of students' information literacy was 1.287 - 1.540, suggesting that there was no collinearity among sub-dimensions. The $\mathrm{t}$ value was $-2.766-16.474$, reaching the significance $(p<.001)$. Therefore, "information processing literacy," “digital media operation literacy," and "basic digital knowledge literacy” all were important explanatory variables affecting students' creativity. The influence of "information processing literacy” was the highest, and that of "digital media operation literacy” was the lowest. The coefficients of "information processing literacy" and "basic digital knowledge literacy" were both $>0$, suggesting that they both had a positive influence on students' creativity. In other words, the higher the students' information literacy competency of "information processing literacy" and "basic digital knowledge literacy" was, the higher their creativity was. The coefficient of “digital media operation literacy” was $<0$, suggesting that it had a negative influence on students' creativity. In other words, the higher the students' information literacy competency of “digital media operation literacy” was, the lower their creativity was. Therefore, H1 was supported.

H1: Students' information literacy has a significantly positive influence on creativity. 
Table 1. Summary of regression analysis on the influence of students’ information literacy on their creativity.

\begin{tabular}{|c|c|c|c|c|c|}
\hline $\begin{array}{l}\text { Dependent } \\
\text { variable }\end{array}$ & $\begin{array}{c}\text { Students' } \\
\text { information literacy }\end{array}$ & $\begin{array}{l}\text { Original score } \\
\text { regression coefficient }\end{array}$ & $\begin{array}{l}\text { Standardized } \\
\text { regression coefficient }\end{array}$ & $\mathrm{t}$ value & VIF \\
\hline \multirow{3}{*}{$\begin{array}{l}\text { Students' } \\
\text { creativity }\end{array}$} & $\begin{array}{l}\text { Information } \\
\text { processing literacy }\end{array}$ & 1.156 & .668 & $16.474^{* * *}$ & 1.287 \\
\hline & $\begin{array}{c}\text { Digital media } \\
\text { operation literacy }\end{array}$ & -.509 & -.116 & $-2.766^{*}$ & 1.386 \\
\hline & $\begin{array}{c}\text { Basic digital } \\
\text { knowledge literacy }\end{array}$ & .648 & .219 & $4.939^{* * *}$ & 1.540 \\
\hline
\end{tabular}

As shown in Table 2 , the $\mathrm{F}$ test value was $48.146(p<.001)$, reaching the significance. $\mathrm{R}^{2}$ was .360, suggesting that the sub-dimensions of classroom climate could explain $36 \%$ of variance of students' creativity. The regression analysis is summarized in Table 2. The analysis found that, the VIF value of sub-dimensions of classroom climate was 2.103 - 3.022, suggesting that there was no collinearity among sub-dimensions. The $t$ value was .574 - 4.141. Therefore, except for "class activity”, sub-dimensions all reached the significance $(p<.001)$. Therefore, "teacher's support," "peer interactions," and “classroom order” all were important explanatory variables affecting students' creativity. The influence of “peer interactions” was the highest, and that of "teacher's support” was the lowest. The coefficients of “teacher's support” and "peer interactions" were both $>0$, suggesting that they both had a positive influence on students' creativity. In other words, the higher the students' perceived "teacher's support”, “peer interactions", and "classroom order" was, the higher the perceived classroom climate was, and the higher their creativity was. Therefore, H2 was supported.

H2: Classroom climate has a significantly positive influence on students’ creativity.

\subsection{Hierarchical Regression Analysis}

Firstly, in hierarchy 1, students' information literacy was used to test the direct influence of students' information literacy on their creativity. As shown in Model 1 of Table 3, the F test value of students' information literacy for their creativity was $300.981(p<.001)$, reaching the significance, suggesting that the regression model had statistical significance. The results of estimation of $\beta$ coefficient showed that, the standardized regression coefficient of students' information literacy for their creativity was .682 ( $\mathrm{t}=17.347, p<.001)$, reaching the significance as well. In addition, the standardized regression coefficient was positive, suggesting that students' information literacy had a positive influence on their creativity. In hierarchy 2, classroom climate was included. As shown in Model 2 of Table 3, after classroom climate was included in the hierarchical regression analysis, the variance explained increased by .081. The change in F value of overall model $(p<.001)$ reached significance, suggesting that the regression model had statistical significance. The results of the estimation of $\beta$ coefficient pointed out that, the standardized regression coefficient of classroom climate for students' creativity was .330 (t $=7.809, p<.001$ ), reaching the significance too. In addition, the standardized regression coefficient was positive, suggesting that classroom climate had a positive influence on students' creativity. Lastly, in hierarchy 3 , the interaction between students' information literacy and classroom climate was used to perform the regression analysis on students' creativity to test the moderating effect of classroom climate on the influence of students' information literacy on their creativity. As shown in Model 3 of Table 3, after the interaction between students' information literacy and classroom climate was included in the hierarchical regression analysis, the variance explained did not increase or decrease. The change in $\mathrm{F}$ value of the overall model was .016, which did not reach the statistical significance $(p<.001)$. The standardized regression analysis of the interaction was .005 , which did not reach the significance $(\mathrm{t}=.127)$. Therefore, the interaction between information literacy and classroom climate in elementary schools did not have an influence on students' information literacy. Therefore, "classroom climate” did not have a moderating effect on the influence of “students' information literacy” on "students' creativity”. Therefore, H3 was not supported. The statistical results are summarized in Table 3.

H3: Classroom climate has a significant moderating effect on the influence of students' information literacy on their creativity. 
Table 2. Summary of regression analysis on the influence of classroom climate on students’ creativity.

\begin{tabular}{|c|c|c|c|c|c|}
\hline $\begin{array}{l}\text { Dependent } \\
\text { variable }\end{array}$ & $\begin{array}{c}\text { Students' } \\
\text { information literacy }\end{array}$ & $\begin{array}{l}\text { Original score } \\
\text { regression coefficient }\end{array}$ & $\begin{array}{c}\text { Standardized } \\
\text { regression coefficient }\end{array}$ & t value & VIF \\
\hline \multirow{4}{*}{$\begin{array}{l}\text { Classroom } \\
\text { climate }\end{array}$} & Teacher's support & .294 & .182 & $2.899^{* *}$ & 2.103 \\
\hline & Peer interactions & .607 & .274 & $4.141^{* * *}$ & 2.349 \\
\hline & Classrrom order & .454 & .190 & $2.529^{*}$ & 3.022 \\
\hline & Class activity & .164 & .037 & .574 & 2.203 \\
\hline
\end{tabular}

${ }^{*} p<.05,{ }^{* *} p<.01,{ }^{* * *} p<.001$.

Table 3. Influence of students' information literacy on their creativity-summary of analysis of classroom climate as the moderating variable $(\mathrm{N}=349)$.

\begin{tabular}{|c|c|c|c|c|c|c|}
\hline \multirow{3}{*}{ Variables } & \multicolumn{6}{|c|}{ Students' creativity } \\
\hline & \multicolumn{2}{|c|}{ Model 1} & \multicolumn{2}{|c|}{ Model 2} & \multicolumn{2}{|c|}{ Model 3} \\
\hline & B cofficient & $\mathrm{t}$ value & B cofficient & $\mathrm{t}$ value & B cofficient & $\mathrm{t}$ value \\
\hline Students' information literacy & .682 & $17.347^{* * *}$ & .512 & $12.103^{* * *}$ & .512 & $12.075^{* * *}$ \\
\hline Classroom climate & & & .330 & $7.809^{* * *}$ & .330 & $7.788^{* * *}$ \\
\hline Interaction & & & & & .005 & .127 \\
\hline $\mathrm{R}^{2}$ & .465 & & .546 & & .546 & \\
\hline $\mathrm{F}$ & $300.981^{* * *}$ & & $207.074^{* * *}$ & & $137.661^{* * *}$ & \\
\hline (p) & .000 & & .000 & & .000 & \\
\hline $\mathrm{R}^{2}$ Change & .465 & & .080 & & .000 & \\
\hline F Statistic & $300.981^{* * *}$ & & $60.986^{* * *}$ & & .016 & \\
\hline (p) & .000 & & .000 & & .899 & \\
\hline
\end{tabular}

${ }^{* * *} p<.001$.

\subsection{Discussion}

\subsubsection{Influence of Students' Information Literacy and Classroom Climate on Students' Creativity} Information literacy emphasizes that it is a problem-solving process. Similarly, creativity is a problem-solving ability. Individuals' ability, especially professional competence, has a significant influence on their creativity (Lin, 2011). Moreover, Chen (2011) suggested that, professional competence is composed of knowledge, skills, attitude, and other ability traits. The meaning of the variable information literacy proposed in this study was also expanded to three aspects: cognition, affection, and skills. Therefore, the professional competency of information literacy is indeed a factor affecting creativity. Moreover, relevant studies also found that, information literacy had a positive predictive power for creativity. The significant correlation between traditional literacy and creativity was particularly mentioned (Liao, 2012). The special finding was that, the higher the students' "digital media operation literacy" in information literacy is, the lower the students' creativity is. Computer operation as an information skill may not necessarily benefit overall information literacy and traditional literacy. Therefore, the improvement of information literacy competency is not simply dependent on digital media operation literacy, but also other aspects. Moreover, regularized operation of computer facilities will not improve creativity, but will ossify thinking and lead to reduced creativity. The dimensions of creativity in this study were divided into creativity competency and creativity tendency. The results showed that both these two dimensions were affected by classroom climate. Students' class activity in the dimension of classroom climate did not have a significant influence. Therefore, class activity did not have a significant influence on students' creativity. The reasons why the influence was not significant were that the intrinsic motivation of individuals might be overlooked, too much attention might be paid to teacher's regulations in class, and students focused on grades, which might lead to poor creativity. 


\subsubsection{Verification of the Moderating Effect of Classroom Climate on the Influence of} Students' Information Literacy on Their Creativity

Classroom operation style not only affects overall classroom climate, but also has a significant moderating effect on students' creativity (Lin, 2010). This study suggested that the reason why the said result is inconsistent with that of this study was that: relevant studies mainly found that context, environment, and atmosphere have a moderating effect on the influence of independent variables of individuals on their dependent variables (Huang et al., 2011; Hsiao, 2011). However, the factors affecting and forming classroom climate were quite diversified and complicated, so general context or atmosphere cannot be used to accurately summarize them. The difference between independent variables and dependent variables also affected the moderating effect. Moreover, the dimension "class activity" of classroom climate did not have a significant influence on students' creativity, which might be the factor leading to insignificant moderating effect of classroom climate. Lastly, one of the reasons why the moderating effect was insignificant might be that the sample size was so small that the result could not reach significance. Wen and Chiu (2011) suggested that, during interaction testing, sample size affects the result of significance testing.

\section{Conclusion and Suggestions}

\subsection{Conclusion}

The research results showed that, the information literacy of higher grade elementary school students was above average. In terms of the mean score of sub-dimensions of students' information literacy, the score of "digital media operation literacy" was the highest, while that of "information processing literacy" was the lowest. Higher grade elementary school students' creativity was above average. In terms of the mean score of sub-dimensions of students' creativity, the score of "creativity competency" was the highest, while that of "creativity tendency" was the lowest. The overall classroom climate of higher grade elementary school students was above average. In terms of the mean score of sub-dimensions of classroom climate, the score of "class activity" was the highest, while that of "classroom order" was the lowest. In terms of the influence of students' overall information literacy on their creativity, students' information literacy had a positive influence on their creativity. In other words, the better the students' information literacy was, the better their creativity was. In terms of the sub-dimensions of students' information literacy, the influence of "information processing literacy" was the highest, while that of "digital media operation literacy" was the lowest. Moreover, the higher the students" "information processing literacy" and "basic digital knowledge literacy" in their information literacy was, the higher their creativity was. The higher the students' "digital media operation literacy" in their information literacy was, the lower their creativity was. In terms of influence of overall classroom climate on students' creativity, classroom climate had a positive influence on students' creativity. In other words, the higher the perceived classroom climate of elementary school students was, the better their creativity was. The sub-dimensions of classroom climate, such as "teacher's support", "peer interactions", and "classroom order", all were important explanatory variables affecting students' creativity. The influence of "peer interactions" was the highest, while that of "teacher's support" was the lowest. In other words, the higher the students' perceived classroom climate in "teacher's support," "peer interactions", and "class order" was, the higher their creativity was. "Class activity" did not have any influence on students' creativity. In other words, students' creativity did not vary with their perceived classroom climate in "class activities". Classroom climate did not strengthen or weaken the influence of students' information literacy on their creativity. In other words, students' information literacy did not change the direction and level of their creativity through students' perceived classroom climate. Classroom climate did not have a moderating effect on the influence of students' information literacy on their creativity.

\subsection{Suggestions}

Government authorities and education-related authorities should develop a project to enable teachers to strengthen the training of information literacy competency and the development of classroom climate through sharing of practical experiences, which may help teachers better understand information literacy and the development of classroom climate. Moreover, mentors with years of experiences and excellent classroom management and those with good information literacy should form professional teacher groups. Teachers may mutually investigate, discuss, and demonstrate the skills of classroom management, the development of classroom climate, and the 
cultivation of information literacy. During the development of relevant measures and educational policies, schools should take into account of students' information literacy-related competency. Mentors should frequently encourage students to ask questions, proactively search information on their questions, arrange data, find out focuses from data, reach conclusions, and share information with other people. Furthermore, mentors should play a democratic, friendly, patient, and good-at-listening role in class. They should design assignments of various types in teaching and encourage and affirm students' expression of diversified ideas. In addition, they should turn a classroom into a harmonious and pleasant environment to enable students to be willing to cooperate, communicate, and discuss with one another.

\section{References}

Amabile, T. M. (2001). Beyond Talent: John Irving and the Passionate Craft of Creativity. American Psychologist, 56, 333-336. http://dx.doi.org/10.1037/0003-066X.56.4.333

American Association of School Librarians (AASL) (2009). Standards for the 21st-Century Learner in Action. Chicago, IL: American Association of School Librarians.

Andretta, S. (2005). Information Literacy: A Practitioner's Guide. Oxford: Chandos Publishing. http://dx.doi.org/10.1533/9781780630755

Bruce, C. (2008). Informed Learning. Chicago: Association of College and Research Libraries.

Eisenberg, M. B., Lowe, C., \& Spitzer, K. L (2004). Information Literacy: Essential Skills for the Information Age. Westport, CT: Libraries Unlimited.

Florida, R. (2004). America’s Looming Creativity Crisis. Harvard Business Review, 37, 122-134.

Gnezda, N. M. (2011). Cognition and Emotions in the Creative Process. Art Education, 64, 47-52.

Hennessey, B. A. (2003). The Social Psychology of Creativity. Scandinavian Journal of Educational Research, 3, $253-271$. http://dx.doi.org/10.1080/00313830308601

Hsiao, C. C. (2011). A Study on Influential Factors of Students’ Creativity: The Three-Level Analysis as Analytic Framework. Journal of Special Education, 33, 151-178.

Hsu, C. W., Chang, Y. L., Wu, I. C., \& Shu, F. P. (2011). Applications of Hierarchical Linear Models on Influence of Creative Climate of Schools and Effective Teaching on Creativity-Teaching Behaviors. Journal of Create, 2, 87-112.

Huang, M. Y., Tu, H. Y., Hsiang, C. Y., \& Lin, T. W. (2011). Relationships of Team Climate, Creativity, and Competition Performance among High School Cheerleaders. Journal of Taiwan Sport Pedagogy, 6, 1-14.

Hunter, S. T., Bedell, K. E., \& Mumford, M. D. (2007). Climate for Creativity: A Quantitative Review. Creativity Research Journal, 19, 69-90. http://dx.doi.org/10.1080/10400410709336883

Liang, J. Y., \& Wei, C. H. (2013). The Mediating Role of Self-Efficacy in the Organizational Climate-Employee Creativity Relationship. Journal of National Taipei College of Business, 24, 47-70.

Mayesky, M. (2005). Creative Activities for Young Children. Stamford, USA: Cengage Learning.

Runco, M. A. (2007). Creativity Theories and Themes: Research, Development, and Practice. Burlington, MA: Elsevier Academic Press.

Shalley, C. E., Zhou, J., \& Oldham, G. R. (2004). The Effects of Personal and Contextual Characteristics on Creativity: Where Should We Go from Here? Journal of Management, 30, 933-958. http://dx.doi.org/10.1016/j.jm.2004.06.007

Simonton, D. K. (2009). Historiometry in Personality and Social Psychology. Social and Personality Psychology Compass, 3 , 49-63. http://dx.doi.org/10.1111/j.1751-9004.2008.00159.x 


\section{Submit or recommend next manuscript to SCIRP and we will provide best service for you:}

Accepting pre-submission inquiries through Email, Facebook, LinkedIn, Twitter, etc.

A wide selection of journals (inclusive of 9 subjects, more than 200 journals)

Providing 24-hour high-quality service

User-friendly online submission system

Fair and swift peer-review system

Efficient typesetting and proofreading procedure

Display of the result of downloads and visits, as well as the number of cited articles

Maximum dissemination of your research work

Submit your manuscript at: http://papersubmission.scirp.org/ 